\title{
POR UM CINEMA INFILTRADO: ENTREVISTA COM ADIRLEY Queirós E MAURÍlio MARTins A PROPÓSITO DE BRANCO SAI, PRETO FICA (2014)
}

\author{
Alfredo Suppia; Paula Gomes*
}

Branco sai, preto fica (2014), de Adirley Queirós, mescla documentário e ficção científica para discutir a cidadania e os direitos civis sob a alça de mira do estado. Vencedor do Festival de Brasília de 2014, este longa-metragem recorre ao artifício da viagem no tempo para tratar de um fato real ocorrido em meados dos anos 1980, quando policiais invadiram o Quarentão, baile de black music organizado na cidade de Ceilândia, na periferia da capital federal, e agrediram violentamente os jovens negros que se encontravam no local. O título do filme remete à ordem de um dos policiais agressores, o qual teria ordenado que apenas os brancos deixassem o recinto do baile.

O filme de Queirós é ambientado num futuro próximo indeterminado em que a segregação centro-periferia persiste e se intensifica. As populações periféricas são excluídas da capital, notícias de rádio e comunicados sugerem um estado policial racista e o trânsito de pessoas no plano piloto de Brasília só é permitido mediante apresentação de um passaporte.

Branco sai, preto fica se estrutura em torno do seguinte eixo: um viajante do tempo, Dimas Cravalanças (Dilmar Durães), chega a Ceilândia num futuro próximo, mas indeterminado, onde vivem dois personagens

\footnotetext{
* Alfredo Suppia: Universidade Estadual de Campinas - UNICAMP, Depto. de Cinema, Pós-graduação em Multimeios. 13083-854, Campinas, Brasil. E-mail: alsuppia@gmail.com Paula Gomes: Doutoranda. Universidade Estadual de Campinas - UNICAMP, Depto. de Cinema, Pós-graduação em Multimeios. 13083-854, Campinas, Brasil.

E-mail: paulagomesrtv@gmail.com
} 
"reais": o radialista Marquim, interpretado por Marquim do Tropa, e o mecânico de próteses Sartana, interpretado por Shockito. Esses dois personagens, que na verdade se confundem com os atores, sobreviveram à noite de violência policial no Quarentão, trazendo em seus corpos a marca da agressão. Marquim ficou paraplégico após levar, indefeso, um tiro da polícia. Sartana/Shockito perdeu uma perna depois de ser pisoteado pela cavalaria policial. Os depoimentos de Marquim do Tropa e Shockito são costurados a cenas ficcionais em que ambos conduzem um plano de vingança. Nesse futuro alternativo de Ceilândia, os sobreviventes Marquim e Sartana pretendem explodir Brasília com uma "bomba sonora", um artefato apocalíptico que inclui variedades da música popular de periferia.

A máquina do tempo que transporta Dimas Cravalanças é uma espécie de contêiner improvisado e, assim como em La Jettée (1962), de Chris Marker, ou Je t'aime, Je t'aime (1968), de Alain Resnais, pouca ou nenhuma explicação sobre tecnologia sofisticada é necessária para justificar a viagem no tempo. No caso do filme brasileiro, ao invés da cura de uma epidemia ou de um caso de amor perdido, o viajante do tempo precisa reunir provas da responsabilidade do estado brasileiro sobre o incidente no Quarentão de Ceilândia, o qual resultou na morte e mutilação de civis. No futuro mais distante, o Brasil se encontra no banco dos réus por crimes cometidos contra sua população negra e pobre.

Gostaríamos de salientar dois aspectos particularmente originais em Branco sai, preto fica: o fato de este filme ser a um só tempo uma curiosa experiência de circuit bending e um digno representante sul-americano do que se convencionou chamar de borderlands science fiction. Circuit bending porque se trata de um filme híbrido de documentário e ficção científica, feito com verba concedida a partir de um edital público destinado à realização de filmes documentários - conforme depoimento de Queirós aos autores desta resenha, e em entrevistas como a concedida a Claudio Reis, Maurício Campos Mena e Raquel Imanishi (2013). Essa “torção” de 
um edital originalmente voltado à realização de documentários, resultando num filme misto de documentário e ficção científica com razoável sucesso de público e crítica, parece ratificar eventuais afinidades operativas já apontadas por Suppia (2009: 13-22), fenômeno ainda mais explícito no caso dos mockumentaries (pseudo-documentários). Diegeticamente, Branco sai, preto fica recorre a toda sorte de circuit bending narrativo, cenográfico e da mise-en-scène no sentido de provocar o "estranhamento cognitivo" em paisagens e circunstâncias aparentemente familiares e corriqueiras - refirome ao estranhamento cognitivo nos termos de Darko Suvin, em seu livro Metamorphoses of Science Fiction, originalmente publicado em 1979.

Como um amálgama de documentário e ficção científica, Branco sai, preto fica é também um filme limítrofe, híbrido em termos de gênero e regime de representação - e também diegeticamente sua fábula se situa num território de fronteira, aquele que separa Brasília, a capital federal, do município de Ceilândia, endereço da classe subalterna ou classe trabalhadora. Narrativa fronteiriça entendida aqui como borderlands science fiction nos termos de Lysa Rivera (2012), Branco sai, preto fica soma-se a filmes latino-americanos anteriores de ficção científica cujas fábulas também se situam em zonas de fronteira, casos de La sonámbula (1998), de Fernando Spiner, ou Sleep Dealer (2008), de Alex Rivera, entre outros.

Enquanto trans-border fantasy, no sentido de fábulas que especulam sobre o trânsito de personagens entre zonas interditas ou interditadas - a exemplo do já citado Sleep Dealer, ou ainda da própria série brasileira 3\%, concebida por Pedro Aguilera e dirigida por Daina Giannecchini, Dani Libardi e Jotagá Crema (www.youtube.com/watch?v=R_rvS7nX7pM), Branco sai, preto fica reinsere o multiculturalismo brasileiro na pauta não apenas do cinema, mas da ficção científica nacional (por mais tênue que sua interface com o gênero possa vir a ser). E com uma particularidade em relação a demais fábulas de fronteira: as geografias acidentadas e zonas de interdição não se restringem aos cenários ou paisagens por onde transitam 
os personagens; elas se inscrevem em seus próprios corpos, na mutilação que os limita e interdita. "Índices" que intensificam o apelo documentário da ficção científica de Adirley Queirós, os corpos mutilados em Branco sai, preto fica são eles próprios "cartografias" da violência ou "mapas" da interdição, "geografias" alteradas pelo uso da força do estado. Esses corpos submetem-se a um duplo regime (o da ficção e o do documentário), à medida em que, por um lado, são legalmente impedidos de cruzar as fronteiras de Ceilândia e, por outro, não mais conseguem realizar as coreografias que costumavam apresentar no baile do Quarentão, devido às óbvias dificuldades de locomoção resultantes do confronto com os policiais. Se a movimentação da periferia para o centro é limitada ou proibida, agora até a dança, o movimento expressivo em seu próprio ambiente, é finalmente confiscado aos excluídos.

Na fábula de Adirley Queirós, a barreira geopolítica que exclui a periferia de Brasília do Plano Piloto deixa sua marca no corpo dos oprimidos: é mais difícil e trabalhoso locomover-se com a necessidade de próteses ou cadeira de rodas. O corpo, em Branco sai, preto fica, é uma geografia tão violentada quanto a do Planalto Central, ou de outros centros urbanos brasileiros. E as cenas de deslocamento de Marquim e Sartana, por mais "estranhadas" pela mise-en-scène que elas possam parecer (o elevador adaptado na casa de Marquim, a oficina de próteses onde trabalha Sartana), são também um retrato fiel de uma realidade nossa contemporânea muito bem conhecida, porém sempre ocultada, interdita, ou referida de passagem: o fato de que o Brasil pune fisicamente seus excluídos, todos os dias, com acidentes de trabalho e/ou acidentes de percurso (no trajeto para o trabalho ou no trajeto para o lazer). Os corpos em Branco sai, preto fica remetem ao extra-filme da infra-estrutura de transporte público no Brasil, dos planos urbanísticos, das ruas e calçadas que bem conhecemos. Por que tão poucos deficientes físicos circulam pelas ruas brasileiras em comparação com 
países desenvolvidos? Porque, no Brasil, a rua (o espaço público) ainda não é lugar de deficiente físico.

E, diferentemente das bem conhecidas "narrativas de superação", Branco sai, preto fica não contemporiza. Os corpos mutilados não terminam por recuperar a dança, por criar novas coreografias com o recurso a cadeiras de rodas ou próteses. Sua expressão é contida. O desfecho é mesmo a explosão do centro irradiador da opressão - explosão esboçada em desenhos, vingança interditada ao cinema brasileiro.

Por fim, gostaríamos de lançar ao debate a hipótese de que tais transborder fantasies, ou borderlands science fiction films (filmes de ficção científica de fronteira), têm oferecido, ao longo dos últimos anos, uma moldura narrativa e uma "paleta de cores" bastante úteis à representação, à problematização e até mesmo ao ensaio sobre temas da agenda contemporânea, notadamente o recrudescimento dos nacionalismos, a xenofobia, o acirramento do estado policial, os rearranjos em termos de fluxos migratórios nacionais/internacionais e a convivência multiétnica ou multicultural. Também faz parte desta hipótese a suspeita de que, com sua ficção especulativa ambientada em geografias limítrofes ou transicionais, os filmes de ficção científica de fronteira têm recorrido com frequência, direta ou indiretamente, a preceitos marxistas revisitados em sua problematização do futuro próximo.

A seguir oferecemos a íntegra de uma entrevista gravada com Adirley Queirós e Maurílio Martins em 12 de junho de 2015, em Brasília, no âmbito do projeto de pesquisa "O pensamento cinematográfico independente brasileiro: história, formas, questões e cartografias", conduzido no Programa de Pós-graduação em Multimeios, da Universidade Estadual de Campinas (UNICAMP), e financiado por linha de fomento Demanda Universal CNPq (CHAMADA UNIVERSAL- MCTI/CNPq N ${ }^{\circ}$ 14/2014). 
Maurílio Martins trabalha na produtora Filmes de Plástico (www.filmesdeplastico.com.br/). Bacharel em Audiovisual pelo Centro Universitário UNA, é produtor, roteirista e diretor. Editor da Revista Lateral (www.revistalateral.com.br), é sócio-fundador da Filmes de Plástico. Dirigiu os filmes Pisciana, 23, calibre .380 (DV, 2006), Descriação (anotações para um anti-filme) (DV, 2008), Pêlos de cachorro (HDV, 2010), Contagem (35mm, 2010) e Estado de sítio (HD, 2011).

Adirley Queirós é diretor e roteirista do filme Rap: $O$ canto da Ceilândia (2005), vencedor do Festival de Cinema de Brasília de 2005 nas categorias júri popular e júri oficial e de outros 13 prêmios no Brasil. Diretor, roteirista e produtor executivo dos filmes Dias de greve (2009) e Fora-de-Campo (digital, documentário, 2009), vencedor do DocTV no Distrito Federal. Dirigiu também os filmes A Cidade é uma só? (2013), vencedor do Festival de Tiradentes-MG, e Branco sai, preto fica (2014), vencedor do Festival de Brasília.

$\mathrm{Na}$ seguinte entrevista, Adirley e Maurílio falam de cinema independente, métodos de trabalho, políticas públicas de fomento, o papel das produtoras e distribuidoras, mercado audiovisual e cinema de ficção científica no Brasil.

ALFREDO SUPPIA: Eu queria saber de vocês, que já têm uma história em termos de cooperativa de cinema, de realização independente, se ainda podemos falar de um cinema independente brasileiro. Se isso ainda faz sentido, se todo mundo é independente, ou se ninguém é independente. Como vocês se colocam nesse cenário? Qual é a relação de vocês com as políticas de fomento, qual o seu grau de dependência dos editais? Qual o método de trabalho de vocês?

ADIRLEY QUEIRÓS: Eu acho que essa história de independente brasileiro tem várias coisas. Tem a questão financeira, obviamente, que é 
determinante sim; e eu acho que tem uma questão de temas, tem uma questão estética, tem uma questão política e econômica. Eu acho que existe o cinema brasileiro independente, mas cada vez menos, porque a política do edital no Brasil é muito presente, e isso é muito bom. Então um certo cinema brasileiro, que durante cinco ou dez anos trabalhou com independência econômica, já não trabalha mais, porque mesmo tendo pouco dinheiro, tem algum dinheiro. O Branco sai preto fica tinha dinheiro de edital. Dinheiro pouco, se pensar que a gente tinha liquido 250 mil reais. E a gente trabalhou durante um ano pagando todo mundo. A gente tinha cinco pessoas recebendo por mês pra estar no filme, fora atores, cenários, etc. Então era muito pouco dinheiro para aquele filme, tinha que inventar muita coisa pra que aquilo acontecesse. Mas eu acho que é independente sim no modelo de produção. É um modelo de produção que se impõe sobre o filme.

Mesmo os filmes no Brasil que são feitos com pouco dinheiro às vezes, ou sem nenhum dinheiro, têm uma dependência política muito forte, eles têm uma coisa de concessão política, então eles não transformam aquela forma do filme em algo que poderia trazer um viés político. Não é só a questão econômica, é a questão de como essa forma do filme se relaciona com o modo de produção. Porque todo filme é modo de produção. Se você tem um real ou mil reais você vai ter que adaptar seu filme ao modo de produção. Se você quer construir uma nave espacial e só tem mil reais, você tem que adaptar aquilo lá a isso. Então eu acho que a forma do filme tem uma independência em relação ao modelo de produção. As pessoas saem da universidade com um exemplo muito rígido de modo de produção, de que pra fazer um filme tem que ter ordem do dia, tem que ter equipe grande, tem que ter dez pessoas etc., e o primeiro filme deles nunca vai ter isso, não se consegue dinheiro pra isso. Então você adapta o modelo de produção, você cria um modelo de produção, e aí eu acho que nasce o cinema independente. Desde Sganzerla, desde Carlão, desde Tonacci, desde Glauber em seu 
primeiro filme, como eles lidavam com esse modelo de produção que gere o filme.

Então existe sim o cinema independente brasileiro, principalmente a Filmes de Plástico do Maurílio, por exemplo, existe o cinema independente na Paraíba que é muito forte, e o nosso cinema de certa forma é independente. Mas eu acho que não é necessariamente porque o filme tem o lugar de algumas temáticas que ele já é automaticamente independente. Tem temática, por exemplo, que supostamente está fora de um padrão de filmes consagrados, mas o filme já tem uma dependência de forma de produção. Então não é porque tem pouco dinheiro que é independente, ele pode ter pouco dinheiro às vezes, mas pode ter toda uma estrutura de modelo de produção que é dependente. Imagine assim, o cara está no quarto filme dele, e ele tem 100 mil pra fazer o filme, aí ele cria um modelo de produção que significa trinta pessoas no set, grua, um monte de coisa, aí ele fala "o meu cinema é independente". Não é independente. É até uma apropriação de mão-de-obra porque, através de uma legitimidade que ele tem, está impondo às pessoas que elas trabalhem de graça para o seu filme. $\mathrm{O}$ modelo que ele está impondo é o modelo de produção grande. Serve pra ele, e pode ser um grande filme, mas não foge do modelo clássico, e é tão perverso quanto, inclusive porque, se ele está no quarto filme dele, e ele quer fazer um filme assim, é direito dele, mas ele tem que captar recurso, a obrigação dele é empregar pessoas. Então tem muitas nuances para o que seria o cinema independente, seja da forma, seja política, seja econômica, e tem o modo de produção mesmo.

MAURÍLIO MARTINS: Essa emulação eu acho que é até um aspecto fundamental, essa emulação de um modo de produção. Por exemplo, o inverso acontece, mas há também um cinema atrelado aos editais. E voltando à sua pergunta, de como é sobreviver sem esses editais, é praticamente impossível. Nós tivemos ciclos irregulares de indústria, nós 
nunca tivemos uma indústria nacional, só tentativas, que eram emuladas também. Até as tentativas aqui não se pareciam com sistema americano, que é de onde eles copiavam. E aí esse cinema que resta hoje, ele está baseado em edital, mas até dentro destes editais há uma gradação muito grande. Por exemplo, o Adirley filma o Branco sai preto fica com um edital pra documentário que dá a ele líquido 240 mil reais. Esse filme novo que nós vamos dirigir agora, tem o mesmo valor. O André Novais faz o Ela volta na quinta [produzido pela Filmes de Plástico, lançado em 2014] com 100 mil reais de um edital de curta-metragem e se adapta a isso. E aí eu acredito que eu posso chamar de cinema independente, e chamaria dentro dos conceitos que o Adirley fala, porque ele vai lá, coloca uma equipe mínima, e consegue estabelecer um filme com uma narrativa do modo que ele queria, mas dentro de uma possibilidade real, que eram 5, 6 pessoas dentro de um set, um filme enxuto, que não tem nada a ver com esse modelo engessado, grande, com equipes saturadas.

Mas dentro até desse sistema de editais você tem esses níveis. Tem desde cara adaptando filme a um recurso mínimo, como tem filmes de 1 milhão, e que chamam de independente. Não sei qual é a lógica, mas chamam. Até mesmo o conceito da ANCINE das Produtoras Independentes Qualificadas, para todas as produtoras. Então acho que o conceito é complicado porque, por exemplo, se a gente vai falar do cinema do pessoal do sul, o pessoal do trash, como o Petter Baiestorf, é uma turma que faz um cinema independente no sentido de ajuntamento de amigos, e que sobrevivia com venda de DVDs. Você tem que restringir isso até a pessoa que tem uma estrutura um pouco maior, pois todos se autodenominam independentes. A grande questão é (e aí eu concordo plenamente com o Adirley) o modo de produção, é como isso é feito, de que forma esse filme é feito, de que forma que há a apropriação do sistema pra esses filmes. 
AQ: Isso joga com várias questões. A questão dos editais por exemplo, o que é o edital no Brasil, e como existe hoje uma política no país de falar de uma certa indústria [do cinema], que é esquizofrênica. Indústria de que no Brasil? Não existe indústria no Brasil. O edital é uma luta histórica de pessoas do cinema independente. Se pegar o cinema independente brasileiro desde o Cinema Marginal paulista, ou até anteriormente, eles lutaram para que houvesse uma lei de incentivo que pudesse ajudar minimamente. Eu acho que tem esse lugar também do edital que tem que ter cuidado, porque o cinema independente jovem, não o mais antigo, outra geração, um pouco mais jovem que a gente, tem um discurso de que "o dinheiro não é importante". Mas aí tem uma questão de classe, porque o lugar de classe fala assim: "o dinheiro é ruim para o cinema". Não, o dinheiro não é ruim pra o cinema, tem dinheiro de monte, quem trabalha tem dinheiro, o problema não é isso não.

As grandes empresas começaram a sacar isso, elas sabem que existe uma demanda política no Brasil, é obvio. No governo Lula e no governo Dilma o audiovisual faz parte da pauta política brasileira, porque eles têm uma questão principal que é a de incentivar as TVs públicas, e incentivar que produções nacionais aconteçam. As grandes empresas sacaram isso e começaram a se apropriar dos editais, a terceirizar os editais, e é a coisa mais absurda do mundo. Por exemplo, tem a DF Cine, tem a SP Filme, tem a RioFilme, que são o maior caô (sic) do mundo, a maior malandragem do mundo. Eles chegam pra vocês e falam "vocês agora são artistas, pronto, vocês são artistas; e vocês vão ganhar 100 mil reais. Nós somos o mercado, e nós vamos ganhar 3 milhões". Então eu quero ser o mercado, não quero ser artista. Artista é o c******, porque vou ganhar 100 mil, e você vai ganhar 3 milhões. Então é esse lugar que eles colocam que é muito absurdo, e eu acho que a gente, talvez nesse discurso nosso de cinema independente, que é cinema independente mesmo, de (sic) correria, a gente perde um pouco da noção política, pois existe uma malandragem por trás disso, existe 
uma perversidade por trás disso. Esses caras que historicamente ganham dinheiro, eles vão buscar ganhar dinheiro em cima da nossa luta histórica e política. Então é só isso que eu fico preocupado quando fala "lançamos DVD" e "a gente faz sem dinheiro". Sim, fazemos, até os 25 anos a gente faz, com 30 vai ficando mais difícil, com 35 a gente precisa comer...

Eu estou falando de coisa pouca, você imagina, se você ganha em uma cidade igual Brasília, 3 mil reais por mês, é um dinheiro pouco pra viver... Isso é independente, fazer cinema assim é loucura. Nos meus filmes, em todos eles, no tempo de trabalho a pessoa não ganha menos de $3 \mathrm{mil}$, nem o ator nem a equipe técnica. Eu estabeleço no edital um valor com o qual eles possam minimamente viver.

MM: É porque você se adequa. Uma coisa que eu acho que vale a pena levantar são essas questões, até mesmo para que não se cultive o rótulo de que quem quer fazer cinema independente não precisa de dinheiro, ou que está abrindo mão de dinheiro. Eu não estou abrindo mão de dinheiro nenhum e acho que o Adirley também não está. Pelo contrário, quero brigar. Uma das coisas que acho interessantíssima é que no edital do Fundo Setorial, o PRODECINE 3, tinha lá pra produção de filmes com "baixo orçamento", mas dentro da estrutura já consolidada, que são filmes de até 1,5 milhão, 2 milhões se eu não me engano. Igual o B.O., a mesma lógica que a do B.O. Mas o PRODECINE tinha uma coisa que era interessantíssima que era não exigir o comprometimento com distribuidoras, porque eles partiram da ideia de que quem fosse fazer aquilo podia ser capaz de gerenciar aquele dinheiro e não atrelar o projeto a uma distribuidora. E aí houve reclamações. Eu ouvi produtoras e produtores consagrados falando assim: "que absurdo, como vão entregar essa grana toda a uma pessoa, e ela não tem sequer uma distribuidora por trás". Mas o pensamento da distribuidora está muito atrelado a: "se existe um cinema independente, então é dependente de uma distribuidora". Só que quem garante que seu 
filme vai ser distribuído? E quem garante que aquela distribuidora valida o seu caráter, que você realmente vai levar aquele projeto até o fim? É a distribuidora que vai garantir isso? Ou seja, é a dependência de algo externo que vai garantir isso? Eu sei que a discussão é muito mais profunda, mas me preocupa, porque é quase como um atestado que diz assim: "vocês não são capazes, nós somos".

AQ: Difícil é gerenciar 100 reais. 2 milhões é mais fácil. [risos]

MM: Exato. "Ah, a Filmes de Plástico e a 5 Da Noite fazem filmes independentes, vocês gerenciam 500, 600 mil e fiquem satisfeitos com isso, e nós continuamos a movimentar". Então é difícil, a pecha do independente é linda no sentido de ser independente politicamente, ser independente de um certo sistema, mas deixar esse estigma ficar colado neste sentido econômico, no de que "Ah, vocês fazem um cinema barato, que bom, continuem aí”, eu acho isso muito perverso, porque aí sim é a luta de classes que continua dentro do cinema, e continua igual aqui fora. E eu, por mim vou brigar contra isso a vida inteira, e vou brigar sim pra que existam editais B.O. de 1,5 milhão, 2 milhões para produtoras como a nossa, porque nós somos capazes de movimentar esse dinheiro sim e continuar sendo independentes de uma série de coisas. E eu não quero estar atrelado a uma distribuidora que não vai sequer me garantir que meu filme vai ser distribuído.

AQ: Se fala muito "edital é isso, edital é aquilo", mas não tem outro modo de ser mais público, de ser mais democrático. Qual o modo mais democrático que ainda existe sem ser o edital? É uma perversidade, é difícil, a gente sabe que tem muita coisa subjetiva, mas é engraçado que ninguém questiona, ou questiona só agora. Ninguém questionava a relação que existia de quem entrava na universidade, por exemplo, quem eram os alunos que 
estavam na universidade. Então ninguém discutia o mérito da universidade, mas em relação ao mérito do edital, se discute. Tem muita coisa envolvida porque eu acho que nesse momento há muita gente envolvida. É isso. O dia que acabar essa grana, ninguém fala mais sobre isso.

O cinema independente então gira em torno de duas questões, desde a questão política, da promoção do edital, até a questão de forma mesmo, porque não adianta nada dizer que é independente e reproduzir tanto valores estéticos como ideológicos de formas perversas. Tem cinema independente de massa, feito com pouca gente, mas o filme tem uma vontade enorme de ser novela (nada contra), ou de ser filme americano (nada contra também), mas eu não vejo onde está a independência nisso. Às vezes parece muito mais que é uma coisa de classe mesmo, um grupo de garotos que quer fazer filme (que é massa), pois eles têm dinheiro, então eles podem fazer. Um cara fala assim: "eu fiz um filme com 50 reais". Mentira! A câmera veio de algum lugar, o carro veio de algum lugar, isso já é valor agregado, que é de classe, pronto. Isso ai é perverso em relação às pessoas que não têm aquilo, e que querem fazer. Essas pessoas vão ter que produzir uma câmera, produzir um carro, produzir uma comida.

MM: É o discurso do filme gratuito. "Fiz o filme de graça". Você não fez de graça porque as pessoas que trabalharam nele não receberam. Não existe isso de filme de graça.

AS: Achei ótimo o depoimento de vocês porque vocês tocaram em um ponto essencial, que é essa questão de como o independente hoje tem um lado perverso também. Há duas faces dessa moeda: se por um lado o cinema independente favorece uma renovação em termos de estética, de forma, sangue novo que entra, novas gerações, etc., por outro lado ele acaba sendo prontamente cooptado pelo sistema, no sentido de manter o mercado meio que reservado para alguns peixões. 
AQ: Grande parte dos nossos amigos estão discursando e defendendo a universalidade de privilégios. Não há como você olhar politicamente para um certo grupo e não ter consequências. É obvio que vai ter consequências. Não existe você pregar um discurso independente e ao mesmo tempo se alinhar com algumas questões.

MM: O problema são esses conceitos também (por isso que eu falei que a discussão é muito além), porque são conceitos que a gente se apropria do sistema americano, o conceito de independente, que são filmes feitos fora dos sindicatos.

AS: Fora dos estúdios também...

MM: Fora dos estúdios... Hoje até menos fora do sindicato, porque no início eram os filmes da TROMA, que eram filmes feitos completamente fora dos sindicatos, então eles tinham que fazer tudo independente mesmo, porque a distribuição, a produção, não eram atrelados a nada. Hoje em dia eu vejo filmes americanos de 50 milhões que são chamados independentes. Um filme independente americano custa 50 milhões de dólares! Então até estes conceitos se embaralham e a gente se apropria disso igual a vários outros conceitos que fomos cooptando ao longo do tempo. E eles se embaralham, ainda mais no Brasil, onde nós temos essa coisa esquizofrênica: dizemos que nunca existiu indústria, mas existiram tentativas como a Cinédia, e outras; os editais vão e vêm; uma época tem muito dinheiro, depois some.

AQ: A questão da garantia eu também acho muito complicada. Se você procura uma vanguarda é o Estado, não é o mercado, mercado não promove vanguarda. O Estado tem direito de ser vanguarda na educação, na saúde, em todos os lugares. Faz parte da Constituição Brasileira, está no artigo 
quinto. Então a obrigação do Estado é ser vanguarda. Nos editais de 10 filmes, se 2 forem bons está ótimo. É risco mesmo. É um risco que o Estado tem que correr porque tem muito dinheiro na parada. O Estado banca cinema, banca obra, banca pista, banca tudo. Toda a movimentação econômica brasileira é do Estado. Então se coloca que o cinema tem que ter essa obrigação de dar certo. O que me incomoda é que parece que o dinheiro do Estado tem que ter uma garantia. Garantia de quê? De que o filme vai dar certo? Impossível. Se houvesse garantia os filmes americanos todos davam certo. Porque os caras trabalham com pesquisa, então garantia não tem de nada. Mas essa premissa da burocracia, de que o cara vai usar o dinheiro pra fazer o filme, isso eu concordo plenamente. Tem que ser feito isso. Isso é o mínimo.

AS: É a garantia sobre o que foi proposto. Não que ele vai ter sucesso ou não, isso é imprevisível.

AQ: Eu acho que tem que administrar o dinheiro bem e aplicar o dinheiro no filme. Isso é obrigação sua. Agora, fora isso, não tem garantia de nada. Ainda acho que o dinheiro do Estado é um dinheiro que é pra ser de risco. Porque é através destes riscos que você cria uma possibilidade de linguagem. Fora isso, não existe. Como você vai criar risco em novela? É engraçado que as minisséries da Globo estão antenadas nessas vanguardas, tanto a européia como a brasileira, e pegam algumas dessas formas de vanguarda e aplicam na minissérie. Pra eles é um risco de público, mas serve como rótulo para passar lá fora. Então eles se apropriam da linguagem do cinema independente, dão uma (sic) gourmetizada nela (de uma forma mediana), e aí eles conseguem que a minissérie vire exportação, conseguem via Itamaraty que vire exportação. E então eles conseguem pontuação para edital. Como esses caras são malandros assim?! Então tem um negócio 
envolvido ai e é hora de discutir como que a gente se encaixa nesse negócio também.

AS: Vou fazer uma provocação ligada a isso: durante muito tempo teve essa discussão na história do cinema brasileiro, que entre os cineastas brasileiros vigorou durante muito tempo o pensamento de que o filme está pronto quando está feita a primeira cópia. O que vocês pensam disso? Vocês querem que os filmes de vocês sejam vistos? Vocês acham que o filme se completa quando vocês conseguem a primeira cópia, ou na verdade que ele se completa quando faz o público? É interessante porque, no caso de Branco sai preto fica, não teve Itamaraty na jogada, não teve nada disso. E é um filme que está sendo muito discutido. Como vocês vêem isso? Vocês acham que ainda vale essa coisa de "faço filmes pra mim ou pra satisfazer minha predileção estética", ou não?

AQ: A Sílvia [Cruz] da Vitrine [Filmes] disse que o Branco sai preto fica é o blockbuster do cinema independente porque fez 20 mil pessoas. Eu pensava que ia fazer 2 mil, aí a Joana [Pimenta, fotógrafa portuguesa que mora em Nova York] disse que ia fazer 20. Eu falei "nunca que vai fazer 20. Não existe fazer 20 mil porque a distribuição é muito difícil, não tem dinheiro pra aplicação". Eu faço filmes para as pessoas verem. A minha ideia de fazer filmes é que as pessoas assistam a esses filmes. Mas assistir em festival não faz parte da contabilidade de público, e qualquer filme nosso que entra em festival, só no Brasil ele consegue 15 mil pessoas, se passar em 10 ou 15 festivais maiores. Também não se contabiliza público de escola pública e os nossos filmes passam em todas as escolas públicas, eles pegam os filmes e passam. Sem nenhum recurso de retorno pra gente.

MM: Tem a internet também. 
AQ: Na minha cabeça filme tem que ser exibido. Mas a gente não tem que ficar refém dessa loucura de fazer filmes "para” o público. Quem é o público? Público de festival é meu público? Eu não sei. Público de festival é de classe média alta, então quem assiste aos meus filmes é de classe média alta. Eu acho que o público é um termo fascista: quando dizem "O seu filme não atingiu o público, foi vaiado", eu não sei se isso é bom ou é ruim. É tão legítimo um cara se levantar por não querer ver um filme de festival como é legítimo o cara querer manter uma linguagem do seu filme em um festival. É pra isso que ele é feito. Então eu acho que não é nesse sentido não de "é porque tem público que deu certo", esse raciocínio não funciona.

MM: O cinema é a arte que se difere de todas as outras porque é coletiva (quase sempre), e é por isso mesmo que até o público que rejeita faz parte dessa ideia quando você faz o filme. Porque muitas vezes os filmes são rejeitados hoje, e daqui a 20 anos são redescobertos, retomados, pesquisados, eles caem de novo na internet, e as pessoas acabam redescobrindo o filme.

Além de ser uma pergunta extremamente difícil de ser respondida, acho que no fundo é o processo todo, é óbvio que eu quero que meus filmes sejam vistos. Mas não quer dizer que eu vá brigar e lutar por esse público de um milhão. Talvez um dia eu me contente com isso. Óbvio que eu quero que o filme seja visto, mas até esse público que vê o filme, ele é completamente distinto, você não tem o menor controle sobre isso. É esse público elitizado, de certos festivais. Mas por exemplo, eu fui ao interior do Ceará com meu filme agora, em uma cidade que não tem cinema há 30 anos, e eram pessoas locais mesmo, e aí chegou um rapaz perto de mim que era agricultor, e veio conversar sobre o filme. Ele ficou uma hora conversando comigo sobre cinema, e era um rapaz agricultor que por algum motivo tem interesse em cinema e literatura. Eu nunca imaginei atingir esse tipo de público e de repente você está ali conversando, pois seu filme 
dialoga com aquela pessoa! Então tem isso também. Eu quero que o filme seja visto, agora, como ele vai ser visto, de que forma vai ser visto, é cada filme, cada processo, cada coisa. Eu tenho certeza de que o Adirley deve ter ficado feliz, você fica feliz com isso, com esse público de festivais, com esse retorno. Agora dizer: "eu vou fazer esse filme pra público X”, isso eu acho complicado.

AQ: Eu acho que o festival devia pagar pra gente, e colocar como bilheteria. Parece que os filmes...

MM: Inexistem!

AQ: São um empecilho, um problema, porque não fazem público. Não existe isso! Todo mundo faz público! Todo filme tem um lugar em que as pessoas vão gostar ou odiar um filme assim. Isso também é um lugar perigoso politicamente falando, quando dizem "o filme teve público ou não teve público”. No Brasil existem modelos públicos, que são uma média, mas existem. Não é garantia mas existe um lugar que dá mais possibilidade. Qualquer daqueles atores chatos da globo...

MM: Comédia...

AQ: Comédia racista e homofóbica principalmente, uma câmera horrível e bem iluminada, e atores ( $\mathrm{sic}$ ) coxinhas, pronto. Isso ai é o modelo que a classe média quer ver. Então esse lugar vai ter um certo público. Agora, a gente fazer filme de edital que vai atender esse modelo, pra que isso? Pra que um edital serviria pra reproduzir o que a novela faz? Não que a novela seja boa ou ruim, só estou querendo dizer que a novela é dinheiro de mercado, não é o filme de edital que tem que fazer isso. Tem caras no Brasil que ganham um edital de 3 milhões, pra que esse dinheiro pra eles? Esses 
caras fazem filmes de 30 milhões! 3 milhões teria que vir pra produtora que não consegue captar isso. O dinheiro do Estado é pra promover a atuação de quem não pode atuar no mercado. Se você quer fazer um filme com mais de 3 milhões, você que vá ao mercado e capte isso, é um direito seu.

AS: Branco sai preto fica é um filme de ficção científica brasileiro? Sim ou não, e se é, por que? O que a ficção científica tem a ver com você ou com vocês?

AQ: Eu acho que é um filme de ficção científica sim. Mas não é que é uma ficção científica, é um filme que teve na sua origem uma tentativa de dialogar com esse lugar. Se ele é ou não, é aquilo que a gente falou anteriormente, o modo de produção impõe outras questões. O meu sonho era fazer um Blade Runner [Ridley Scott, 1982]. Queria fazer um Blade Runner. Então o nosso imaginário é Blade Runner, Mad Max [George Miller, 1979], meu exemplo era As crônicas marcianas [The martian chronicles (1950) de Ray Bradbury]. Era sempre essa coisa de girar num tom de um certo lugar de ficção científica, então a gente sai para o filme pensando: esse filme é um filme de ficção científica. Pra mim é um filme assim. Então toda a questão de arte e fotografia e som é um lugar onde dialoga com a ficção científica, um lugar de distopia, de futuro, de distopia social, de uma cidade sitiada, de sons estranhos, de passagem de tempo, tudo isso pra mim é ficção clássica científica.

Obviamente que ele é feito dentro de um edital de documentário, então o imaginário, a fabulação, a ideia coletiva, a impossibilidade, tudo isso está envolvido no filme, mas na minha cabeça ele é um filme de ficção científica sim. Eu acho que existe no Brasil essa possibilidade sim de fazer. Até a Joana [Pimenta] estava brincando hoje porque eu vou fazer um filme agora que começa com uma nave caindo, e alguém falou assim: "a nave na verdade ela não pousa assim (movimento de mãos no sentido vertical), ela 
pousa assim (movimento diagonal)". Ela não pousa na vertical, ela pousa na diagonal. Mas onde está escrito isso? Você já viu uma nave pousar? Quem estabeleceu esse modelo de pouso de nave assim? Se é ficção, se é do espaço, se ele tem outra matéria, se tem outra dinâmica, se ele pode obedecer outras questões físicas, então ele pode fazer outras coisas. Por isso eu acho que a ficção científica tem esse lugar em que você manipula a ordem real da física. Porque tem a ordem da física, a matéria da física, a gravidade, etc. Mas se ele vem de outro lugar, ele por ter uma dinâmica de matemática diferente.

De novo, a ficção científica enquanto forma seria muito interessante para questionar esse lugar ideologicamente imposto de que ela é ficção. O paradigma do corpo, por exemplo... Eu assisti ao Mad Max agora [Mad Max: fury road (2015), de George Miller], e achei incrível, fiquei extasiado com o filme. E é só um filme de atmosfera. O que é o roteiro dele? Ela vai, esqueceu, volta! $\mathrm{F}^{* * * * * * *}$ o roteiro, mas tem uma atmosfera incrível que é a atmosfera do tempo de cinema, a questão dos planos, como ele lida com a questão do incesto, tem várias coisas envolvidas ali no filme, que são muito potentes, do imaginário da ficção. Então eu acho que a nossa ficção pode lidar com esse imaginário também, com essa potência.

Porque se liga à ficção científica a ideia do orçamento alto. Se pensar em ficção científica no meu filme, é muito mais som que imagem. A gente tem muito mais potencialidade de trabalhar sons do que imagem. Só que daí vai pra distribuição... A gente faz um filme que lida com todo um espectro de som, trabalha, e na primeira exibição do filme os caras colocam o filme no mono, uma exibição horrível, que ninguém ouve $\mathrm{p}^{* * * *}$ nenhuma, então lá se foi todo o trabalho do cara. Então tem muito essa coisa de como que a gente vai lidando com essas possibilidades estéticas. Se a gente não pode fazer uma nave espacial potente na sua forma somente de imagens e luzes, a gente pode brincar, a gente pode estabelecer o jogo do filme, e brincar com o som por exemplo. A ficção clássica também era isso, de ter o extra- 
cotidiano, e não o cotidiano. A ficção [científica] na verdade é o extracotidiano, não é o cotidiano. O cotidiano está lá. Mesmo o Branco Saí Preto Fica tem muito um lugar cotidiano, mas é o extra-cotidiano que traz a ficção científica.

AS: Eu acho que algo que o Branco sai preto fica faz (e por isso eu acho que é uma ficção científica brasileira muito potente, representativa) é usar imagens do cotidiano, mas o filme estranha essas imagens. Está tudo estranhado ali de maneira que, por exemplo, aquele depósito de próteses, que obviamente existe, mas do jeito que ele está constituído ali, a atmosfera que é criada automaticamente estranha aquele lugar!

MM: Mas a periferia já é uma ficção científica para a classe média branca brasileira! Ela já é uma ficção científica! Mostrar a periferia no cinema já é algo que provoca.

AQ: Mas o problema é esse mesmo, eu acho que é esse o problema. A Filmes de Plástico é uma exceção maravilhosa, talvez a melhor. Eu acho a Filmes de Plástico a melhor produtora brasileira. Se alguém seria modelo de mercado é a Filmes de Plástico, porque tem uma tentativa de lidar com o popular, tem uma pegada muito forte com o aluno de escola pública... imagina, se você consegue que o aluno de escola pública goste do teu filme, se eu sou do governo eu falo assim: "Pronto! Isso pra mim é cinema popular. Eu posso investir nesse filme que ele pode ser uma nova televisão brasileira, um novo cinema brasileiro".

Mas enfim, o modelo que a periferia tem de cinema é o modelo de classe média, que é a novela. Então ela nega aquilo que ela tem de mais forte, que é aquele lugar de estranhamento. Aquele lugar de estranhamento sim, pode ser um agente de ficção. A forma como ele caminha, a forma como ele chega no ferro velho, a forma que ele tem um carro... 
MM: O gradeamento que você sempre comenta... [Maurílio se refere às grades na arquitetura]

AQ: Mad Max fez isso na verdade...

MM: É isso. E por isso eu acho o filme maravilhoso!

AQ: Esse Mad Max novo roubou minha ideia inclusive, vamos processar ele [risos]. Os caras são mecânicos. Na origem são mecânicos, nesse filme nosso que a gente está fazendo agora a ideia original era essa, eram mecânicos que faziam um monte de carro velho virar uma nave científica. Então os caras são espertos. São espertos pra c******. Essa é a questão. A gente coloca um lugar de vanguarda que é caretíssimo. A nossa vanguarda é o que? Onde está a nossa sensibilidade de vanguarda? A gente fica falando sobre opressão, que o cinema americano é opressor, mas o cinema de Cannes é tão opressor quanto, porque ele estabeleceu um modelo de bom gosto, um modelo de sensibilidade, um modelo de sensibilidade em relação ao espaço, que é lindo, mas é um modelo de sensibilidade europeu. É massa, é tão lindo quanto lá, mas será que pra gente esse é o modelo de sensibilidade? Será que esse "tosco", que eles chamam de tosco nosso não é a nossa potência sensível? Talvez o tosco seja a nossa potência sensível. Talvez aquilo que é mais forte da gente, que é o que eles chamam de tosco, é aquilo que a gente se envolve enquanto cinema. Porque cinema nada mais é do que corpo e atmosfera. Cinema é corpo e atmosfera! Você constrói a montagem, a mise-en-scène de tal forma que chega o momento em que você tem afinidade com o cara, você gosta daquele cara, um cara que fala pouco, que às vezes tem dificuldade de se expressar, que fala errado, que fala rápido... Talvez aquele lugar seja o lugar mais sensível que existe. Então eu acho que a ficção brasileira tem esse problema. Mesmo em relação à 
periferia, tirando exceções, ele tem como modelo o modelo clássico de televisão brasileira.

MM: São os modelos mesmo, são os modelos que são errados. A grande questão é essa. Por exemplo, o filme novo do André Novais, o curta que estava em Cannes agora, tem a coisa do realismo fantástico [Maurílio se refere a André Novais Oliveira, seu colega na Filmes de Plástico, e ao filme Quintal]. A sinopse é "um dia comum na vida de um casal de periferia", que é um dia comum na vida dos pais dele, com esse toque do Murilo Rubião, do realismo fantástico, chegando na ficção científica. E eu vejo que o estranhamento das pessoas não é só pelo que acontece de sobrenatural, é também por ser um casal de negros idosos na periferia! Porque isso também não é colocado no cinema, e por isso eu falo que esse estranhamento é o que mais me encanta no Branco sai preto fica. O gradeamento da Ceilândia, que é algo único, essa arquitetura da Ceilândia, as casas todas frontais, todas na beira da rua, todas com grades... Nada pode ser mais distópico que isso! Nada pode ser mais atemporal, essa coisa maluca, esse tipo de arquitetura... E o Adirley explora isso, isso é explorado no filme, mas isso faz parte da cidade. Está colocada ali como algo que você encara mesmo como futuro, mas aquilo é agora. Se você andar na Ceilândia você vai ver as casas daquele jeito. Mas ele só tem esse olhar porque ele mora lá e não é um olhar forasteiro, não é um olhar estrangeiro. Então eu provoco isso: qual é a fórmula, qual é o padrão, o que a gente está querendo copiar? A gente quer copiar o padrão americano ou a gente pode fazer a nossa própria ficção científica? E esse filme novo [Maurílio se refere ao filme que ele e Adirley estão realizando no momento], ele parte muito disso, parte do que temos, e do que somos.

AQ: Eu acho que a ficção [científica] tem a coisa também do absurdo, assim, a ficção é o absurdo. Eu estou fazendo um filme [Mato Seco em 
chamas] também que vai ser com a Joana [Pimenta], estamos fazendo juntos, que é um filme que parte de uma ideia real, e entra numa ideia absurda, que também é ficção científica. Ele vai entrar numa ideia de que vai nascer petróleo na Ceilândia, o petróleo é nosso. Então partindo deste discurso clássico que move a direita e a esquerda brasileira, que derruba o governo, que está quase derrubando a Dilma (infelizmente, o que seria um golpe perverso e reacionário), derrubou tudo... Se o petróleo fosse mesmo nosso, se nós então furássemos um buraco nessa porra e nascesse petróleo na cidade, o que é um absurdo, e nos começássemos a ressignificar a ideia de transformar o petróleo, de manipular o petróleo como fonte de energia e econômica, isso viraria ficção científica. A ideia do absurdo traria isso. Isso eu acho muito massa, a ficção tem esse lugar também. Ela, mesmo sendo distópica, traz uma utopia de linguagem, isso que eu acho muito bonito! Mesmo um conteúdo distópico, que pode gerar um filme melancólico, um filme que a gente se perca na narrativa, pode trazer essa utopia de que é possível sim, através de narrativa, construir um lugar político. Porque essa narrativa é política! Na medida em que você se apropria e diz assim "eu posso fazer essa narrativa", então você pode fazer cinema, pode fazer literatura, pode fazer música, pode transformar imaginários. Então a ficção tem esse poder muito $\mathrm{f}^{* * *}$ de transformar imaginários. A ficção científica é muito comunicativa, todo mundo se encanta assistindo, o público jovem se encanta vendo isso, remete a aventura, a um corpo que tem mil anos, a um corpo que pode tudo, o próprio ato de fazer o filme, aquela narrativa do filme, ele se faz com um corpo que pode transmitir coisas. Então eu acho muito legal a ficção enquanto absurdo, porque a ficção enquanto modelo de produção clássica tem absurdos normais... Todo personagem de ficção científica é luz, tudo é luz é, sapiência... No nosso filme, por exemplo, a gente quer que o cara seja um peso, um cara que come muita carne, um cara que fala um monte de merda, ele é passado. O futuro é o Brasil, por mais complicado que seja, por mais estranho que seja, por mais pesado que seja, 
o futuro é o Brasil. Não é um cara que vem de 60 [Adirley se refere à década de 1960]. O cara que vem de 60 tá $\mathrm{f} * * * * * .60$ deve ser ruim aqui e em todo lugar do mundo. É por ai.

MM O deslocamento é nele [no personagem em questão].

\section{Referências bibliográficas}

REIS, Claudio; MENA; Mauricio Campos; IMANISHI, Raquel (2013), Entrevista com Adirley Queirós, Negativo, Brasília: Cineclube Beijoca/Universidade de Brasília, v. 1 n. 1, jul/set, pp. 16-69.

RIVERA, Lysa (2012), "Future Histories and Cyborg Labor: Reading Borderlands Science Fiction after NAFTA”. Science Fiction Studies. Vol. 39, No. 3 (November), pp. 415-436. Disponível em: http://www.depauw.edu/sfs/pioneers/rivera118.html.

SUPPIA, Alfredo (2009), "Afinidades operativas entre cinema documentário e cinema de ficção científica", Cadernos da Pósgraduação Multimeios, Edição Especial Cinema e Fotografia, Vol. 10, pp. 13-22).

SUVIN, Darko (1979), Metamorphoses of Science Fiction: On the poetics and history of a literary genre, New Haven: Yale University Press. 